\title{
Towards restoration of human identity: Practical Theology exploring possibilities of re-imagining the discourse of reconciliation and social cohesion in South Africa
}

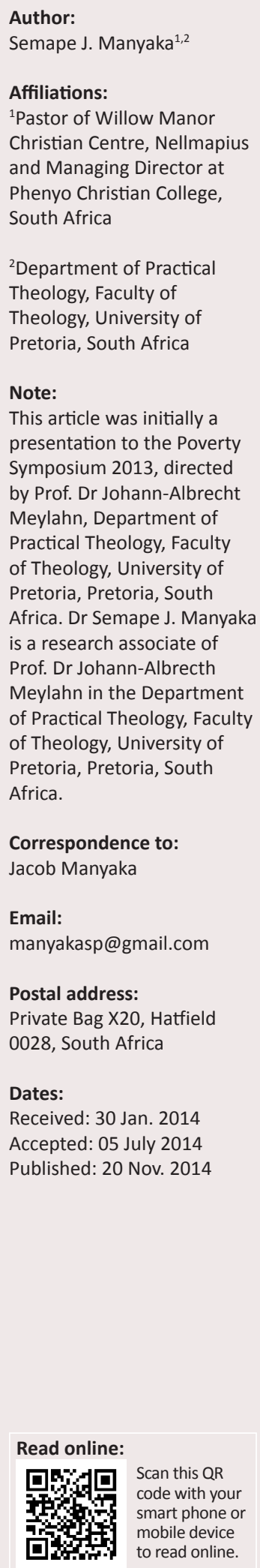

'Social cohesion' is a concept that many researchers agree is not easily defined. However, all definitions do agree that it is about a combination of processes. In this article I have adopted the Jenson definition (1998:4), as 'a process of developing a community of shared values, shared challenges and equal opportunities within South Africa, based on trust, hope, and reciprocity among all South Africans'. Through this process the restoration of human identity will emerge out of the fragmentation caused by the apartheid government before the new democratic order of 1994. It is the aim of the new government to engage in this process (Cloete \& Kotze 2009:43), with the result that many of those with broken human identities are beginning to participate in the developing new order. I have also chosen to explore transversal discourses in this article. These discourses favour an interdisciplinary approach. They allow different disciplines to have conversations without assimilation, and, while rooted in their own belief systems, they are still capable of sharing with others. In South Africa, we come from different backgrounds, but our backgrounds should have no power to keep us apart or locked in our own prisons. The article follows the tenets of postfoundationalist practical theology, and is based in the interdisciplinary paradigm. It promotes reflection on the 'presence of God' without using force, or judging those who do not share my faith. In this approach all voices receive equal treatment: participants are free to say what they believe and to express themselves openly; it also means theologians can participate freely in the debate on social cohesion. This is a neverending journey; each one of us must play our role and never give up.

\section{Introduction}

In this article I discuss the possibilities of re-imagining the discourses of social cohesion. Is it possible to re-imagine a society which is cohesive despite diversity?

On social cohesion, President Jacob Zuma said:

Since 1994 we have sought to create a united cohesive society out of fragmented past. We are called upon to continue this mission of promoting unity in diversity and develop a shared value system, based on the spirit of community solidarity and a caring society. Our shared value system should encourage us to become active citizens in the renewal of our country. (Struwig et al. 2011:1)

The following are some of the scars inherited from our fragmented past:

\section{Inequalities}

A Mail and Guardian (2013) article noted:

A January 2013 Oxfam report rated South Africa as the most financially unequal place on Earth. [The report] states that it is now widely accepted that rapidly growing extreme wealth and inequality are harmful to human progress. (p. 1)

\section{Unemployment}

In South Africa, one of the factors most disturbing to social cohesion is unemployment. According to Statistics South Africa, more than half of the population is out of work. Even though there are conflicting opinions regarding the rate of poverty in South Africa, all are agreed that South Africa has one of the highest unemployment rates in the world. This can make social cohesion difficult (Daily Maverick 2014).

How to cite this article: Manyaka, S.J., 2014, 'Towards restoration of human identity: Practical Theology exploring possibilities of reimagining the discourse of reconciliation and social cohesion in SA', HTS Teologiese Studies/Theological Studies 70(1), Art. \#2624, 5 pages. http://dx.doi.org/10.4102/hts.v70i1.2624

Copyright: @ 2014. The Authors. Licensee: AOSIS Open Journals. This workis licensed under the Creative Commons Attribution License. 
Given this picture of fragmentation, I would like to re-imagine the discourses that can turn a highly fraught situation into one of harmony.

\section{Methodology}

The methodology for this article was a literature review in which concepts were tracked across different authors from different disciplines. It is written from a practical theology perspective.

\section{The concept of social cohesion}

As I re-imagine the possibilities of discourses on social cohesion, it is proper to describe the concept of social cohesion. What is it? What are the challenges in achieving cohesive society? How can we reach the possibilities of building cohesive society?

\section{What is social cohesion?}

French sociologist Emile Durkheim (1858-918) was looking at the factors that bind or hold the society together; he introduced the notion of 'solidarity or social cohesion, the ties that bind people to one another, as a conscious category in the study of human society' (Cloete \& Kotze 2009:6). According to Durkheim's theory, harmony is the key factor in a society.

More recent authors define social cohesion as:

- 'The on-going process of developing a community of shared values, shared challenges, and equal opportunity within Canada, based on a sense of trust, hope and reciprocity among all Canadians.' (Jenson 1998:4, for the Government of Canada's Policy Research SubCommittee on Social Cohesion).

- 'A set of social processes that help instil in individuals the sense of belonging to the same community and the feeling that they are recognised as members of that community.' (Jenson 1998:4, for the working group of the Commissariat general du Plan of the French government).

- 'A characteristic of a society dealing with the connection and relations between societal units as individuals, groups, associations as well as territorial units.' (BergerSchmitt 2000:2)

As we can see, social cohesion is not a destination; it is a process to discover what binds people together and what the enemies of this desired unity or solidarity are. Government should lead the national process towards social cohesion, whilst people should ignore things that destroy social cohesion and should strive for things that will bind people together.

\section{Dimensions of social cohesion}

Jenson (1998:15) identifies five dimensions of social cohesion, namely:

1. belonging versus isolation, which means shared values, identity, feelings of commitment

2. inclusion versus exclusion, which concerns equal opportunities of access
3. participation versus non-involvement

4. recognition versus rejection, which addresses the issues of respecting and tolerating differences in a pluralist society

5. legitimacy versus illegitimacy, with respect to institutions acting as a mediator of conflict in a pluralist society.

\section{Identity and social cohesion}

As the people in South Africa begin to feel that they belong to the society; that they are included in the equal opportunities of the new society; that they are participating equally, and they are being recognised in the pluralist society, their personal identities will be restored and social identity will begin to emerge. Unity in diversity will be experienced by all.

Previously, writing about participation (Manyaka 2010:125), I argued 'a participatory process is about helping the poor or a marginalised group to achieve independence from external agents in formulating their own agendas and managing their affairs'. I emphasised the importance of participation again when I wrote 'participation is important in the process of empowerment' (Manyaka 2012:9). Participation is the power that can accelerate the process of social cohesion in South Africa.

\section{The concept of identity}

Identity plays the important role - indeed, may be the core - of reconciliation and social cohesion in South Africa. Therefore, the question arises: What is identity?

Pretorius (1989:12, quoted in Delport \& Olivier 2003), describes personal identity:

$[A]$ s person awareness of the self as a unique individual, and it centres on the questions who am I? Where am I going? And what is the meaning of my life? (p. 180)

Josselson (1987:13) puts it even more simply: '[I]dentity is how the person experiences himself/herself.' Taylor (1989:27) expands on this, by describing personal identity as the commitment, and identification, which provides the frame within which one can try to determine from case to case what is good, or valuable, or what ought to be done.

From these pointers we can deduce that any human being, to function happily, must experience him or herself in a positive way; must be aware that there is a purpose for his or her existence here on earth, and must feel accepted by the entire society. So, we must ask ourselves, what could disturb the way one experiences self?

\section{Things that destroy identity}

We can mention a long list of things that destroy identity; but this article looks at only two: the effects of racism and poverty.

\section{Racism}

Throughout South Africa's history, an ideology of white people being superior to black people reigned, and was 
most actively promoted by the apartheid government over the period 1948-1994. Kim and Foster (2007:48) argue that within this ideology, everything European was considered as good and valued, while everything originating in Africa was de-valued.

During the apartheid era, many laws were passed that reduced black people to an inhuman condition. Black people could not experience themselves as people of value. Their identity was destroyed.

\section{Poverty}

Many labour laws were passed that excluded black people from skilled jobs and managerial positions in companies (Seeking \& Nattras 2005:138). Black people were excluded from sharing the wealth of the country and slipped into generational poverty. 'Poverty carries with it not only economic burdens but also psychological difficulties' (Mickelson \& Williams 2008:908). It means that poverty destroys the human identity. It causes low self-esteem, selfrejection and self-blame.

\section{Restoration of identity}

Pursuing social cohesion could restore human identity. The government should lead the process of social cohesion. As one of the five dimensions of social cohesion is participation, this can help anyone to experience him or herself as someone of importance.

\section{Transversal narratives}

In postmodern epistemology, strength is dependent on knowing that plurality is the paramount idea, unlike in modern epistemology that stresses singularity in knowledge. In transversal rationality, different disciplines can have conversations to share their understanding. Donald Capps (as quoted in Van Huyssteen 2000:429) states 'transversality identifies different but equally legitimate ways of looking at issues or disciplines'.

Shrag (1992:148) describes transversality in this way: '[It] has appeared on the scene as a recurring figuration of thought across the disciplines for some time.' Shrag notes that different disciplines use different metaphors to explain the transversal rationality; for example:

- Mathematicians define transversality as a generalisation of orthogonality, enabling a line to intersect two or more lines or surfaces without achieving coincidence.

- Physiology employs the grammar of transversality in describing the networking of bands of fibres.

- In anatomy the term is used to define the lateral movement of vertebra.

- Physicists make use of the concept of transvers mass in working out the ratio of accelerating forces.

- In philosophy the concept of transversality has been used to describe the dynamics of consciousness and the interplay of social practices.
Felix Guattari (in Shrag 1992:23) describes a psychiatric practice where different people join forces in helping the patient. There are doctors, assistant doctors, nurses, administrators, patients, parents, and pharmacists. All these people represent different disciplines but they manage to network together.

In all the metaphors above, we see the following: interrelated senses of lying across, extending over, intersecting, meeting and converging without achieving coincidence (Shrag 1992:149).

Van Huyssteen (2007:19, quoted in Müller 2009) elaborates on transversal rationality:

In the multidisciplinary use of the concept of transversality there emerge distinct characteristics or features: the dynamics of consciousness, the interweaving of many voices, the interplay of social practices are all expressed in a metaphor that points to a sense of transition. (p. 204)

\section{Transversal narratives and social cohesion}

I think the transversal narratives can be an instrument for promoting social cohesion in South Africa. South Africa is a multi-ethnic (or multiracial), multi-language, tribal society, each with its own traditions, expectations, social mores, even religions; within this mix there are levels of wealth and education and employment and, most basic of all, the gender split. All of these make social cohesion difficult. All of these make the transversal approach necessary. Despite our differences, we can still share our different spheres of knowledge without fear of being rejected by one another. Though different, we can still have shared vision, shared challenges, and shared equal opportunity, as I outline in my definition of social cohesion.

The doors to opportunities in the economy, education, employment and managerial positions must be opened to all. If this can be achieved, a cohesive society will be possible.

\section{Practical theology}

My work is based on practical theology; therefore I want to elaborate on practical theology and its role in social cohesion. Let me start by asking the question: What is practical theology?

Heyns and Pieterse (1990:7) state simply that 'practical theology interprets the interaction between the gospel and people'. Ballard (1992) describes the work of practical theology in this way:

The special task of practical theology is to start with the concrete, historical, immediate reality, critically evaluating and enabling the practical life of the church in all its forms, drawing on the findings of fundamental, historical, and systematic theology. (p. 29)

Browning (1996:8) says that 'human nature is practical in thinking', and notes that in the actual practice of practical theology, we move from practice to theory and back to practice. Müller (2005:73) argues that postfoundationalist practical 
theology happens whenever and wherever there is a reflection on practice, from the perspective of God's presence. He continues, saying 'it can be very spontaneous, informal, and local' and whilst 'this way of thinking is always concrete, local and contextual, at the same time it reaches beyond local contexts to transdisciplinary concerns' (Müller 2005:77). The postfoundationalist practical theology approach forces us to listen to the stories of people in their real-life situations (Müller 2009:204).

Van Huyssteen (2006:147, quoted in Müller 2011:3) repeats the very important notion of a 'democratic presence' for Christian theology in an open, postfoundationalist conversation. Theology shares the interdisciplinary standards of rationality, and is not hopelessly culture- and contextbound, but is always contextually and socially shaped. In this interdisciplinary conversation with other sciences in a postmodern situation, theology will participate as an equal partner with an authentic voice. I like this term 'authentic voice': it means all disciplines can share freely their beliefs and values without being afraid of judgement from one another. Theology is engaging at this table without thinking that they have absolute truth. With an 'authentic voice', theologians can stand for their spiritual beliefs without forcing them onto other participants.

Müller (2011) describes the foci of holistic pastoral ministry in a context of transition. I think this approach can also give theologians and pastoral ministry an authentic voice in the social cohesion process. It is valuable to note the following foci of holistic pastoral ministry:

- 'Real concern about real [people]. Concerns in this paradigm are never theoretical, but always local and embodied.

- A not-knowing approach, but at the same time an approach of active engagement.

- Holistic in the sense of being fully committed to the real contextual story, but also committed to the exploring of traditions of interpretation.

- A social-constructionist approach where a person is part of the development of a preferred reality that makes sense to him or her. Such an approach creates both the most profound and the most fragile moment, a moment of true pastoral concern.

- An interdisciplinary approach, not on the basis of assimilation, but on the basis of transversal rationality.' (p. 3)

Van Huyssteen (2006:148, quoted in Müller 2011) uses the term:

$[W]$ ide reflective equilibrium to point to the optimal but fragile communal understanding we are capable of in any given moment in time. A postfoundationalist notion of reality enables us to communicate across boundaries and move transversally from context to context, from one tradition to another, from one discipline to another. He continues that in this wide reflective equilibrium, we finally find the safe but fragile public space we have been searching for, a space for shuttling back and forth between deep personal convictions and the principles that finally result from interpersonal judgements. (p. 3)
As we have seen, postfoundationalist practical theology is always happening in the moment of practice. It is not imposed on the context, but is born in the context. It is always local and situated. For these reasons I have chosen postfoundationalist practical theology to play an active role in the process of social cohesion.

Therefore, given this background, I think practical theology could be a way of facilitating the presence of God in a nonfrightening way. Postfoundationalist practical theology is not about imposing ways of how to experience the presence of God, but is more about encouraging everyone to believe that, whatever their context, they can experience the presence of God. It is empowering in nature, especially to those who have been marginalised in the community, so social cohesion can be experienced through the practice of postfoundationalist practical theology.

On 28 June 2014, I attended a fundraising ceremony at an orphanage where I am part of the management team. I listened to a child tell her story: her family had experienced deep poverty in their home, to the extent that sometimes she questioned the presence of God. Her mother, a Christian woman, prayed twice a day, but it seemed the more she prayed, the more problems came. Nevertheless, she said she will never give up her faith in God, but it was frustrating. This is what postfoundationalist practical theology focuses on: it demands that we listen with acceptance to the experiences of people and how they interpret these.

A pastoral ministry based on this thinking has the power to be a facilitator in the continuous development of social cohesion in South Africa. Pastors and ministers work closely in their local contexts. They deal mostly with people who are marginalised and who have no sense of hope because of poverty, inequalities, and unemployment.

\section{Conclusion}

The development of social cohesion must be on the agenda of the government, private sector, church and all the people of South Africa. South Africans must never allow our fragmented past to keep us hostage or imprisoned. All must ignore what divides us, and focus on what binds us as one nation.

Transversal rationality, as a discourse promoting interdisciplinary conversations, can be an instrument of social cohesion. Even though we belong to different disciplines, this is the time to reach out and begin to have conversations with one another.

The restoration of human identities will emerge. People will begin to realise their purpose and why they exist. All the citizens of South Africa will begin to see their responsibility in rebuilding the nation. Postfoundationalist practical theology informs us to focus on the local and immediate contexts where people live. And to work with people, not abstracts. It helps us to do pastoral ministry effectively. 


\section{Acknowledgements Competing interests}

The author declares that he has no financial or personal relationship(s) that may have inappropriately influenced him in writing this article.

\section{References}

'Africa Check: Unpacking the latest unemployment figures', Daily Maverick, 04 November, 2014, viewed no date from http://www.dailymaverick.co.za/ November, 2014, viewed no date from http://www.dailymaverick.co.za/
article/2014-06-26-africa-check-unpacking-the-latest-unemployment-figures/

Ballard, P., 1992, 'Can theology be practical?', in D Willows \& J. Swinton (eds.), Spiritual dimension of pastoral care: Practical theology in a multidisciplinary context, $\mathrm{pp}$. 27-35, Jessica Kingley, Philadelphia, PA.

Berger-Schmitt, R., 2000, 'Social cohesion as an aspect of the quality of societies: Concept and measurement', EuReporting Working Paper No, 14. (Subproject 'European System of Social Indicators', Centre for Survey Research and Methodology (ZUMA), Social Indicators Department, Mannheim.

Browning, D.S., 1996, A foundational practical theology: Descriptive and strategic proposals: Fortress Press Books, Minneapolis, MN

Cloete, P. \& Kotze, F., 2009, 'Concept paper on social cohesion/inclusion in local integrated development plans', Commissioned by Department of Social Development, Republic of South Africa, final draft.

Delport, A.C. \& Olivier, M.A.J., 2003, 'Female students' view of their Afrikaner identity', Society in Transition 34(1), 178-189.

Heyns, L.M. \& Pieterse, H.J.C., A primer in Practical theology, Gnosis Books and Publishers CC, Pretoria.

Jenson, J., 1998, Mapping social cohesion: The state of Canadian research, Canadian Policy Research Networks, CPRN Study No. F/03, Ottawa, viewed 22 May 2014, from http://www.cccg.umontreal.ca/pdf/CPRN/CPRN_F03.pdf

Josselson, R., 1987, Pathways to identity development in women, Jossey-Bass Publishers, San Francisco, CA
Kim, W. \& Foster, D., 2007, 'Investing in discourses of poverty and development: How white wealthy South Africans mobilize meaning to maintaining privilege', South white wealthy South Africans mobilize meaning to maintaining privilege', South
African Review of Sociology 38(1), 45-69. http://dx.doi.org/10.1080/21528586. 2007.10419166

'Debating social cohesion', Mail and Guardian, 03-09 May, 2013, p.1.

Manyaka, S.J., 2010, 'The marginalized stories of people who live in poverty: A pastoral narrative approach to community transformational development', PhD thesis, Department of Practical Theology University of Pretoria, Pretoria.

Manyaka, S.J., 2012, 'Community transformation through people participation', unpublished manuscript.

Mickelson, K.D. \& Williams, S.L., 2008, 'Perceived stigma of poverty and depression: Examination of interpersonal and intrapersonal mediators', Journal of Social and Clinical Psychology 27(9), 903-930. http://dx.doi.org/10.1521/jscp.2008.27.9.903

Müller, J.C., 2005, 'Postfoundationalist, HIV-Positive practical theology', Practical Theology in South Africa 20(2), 72-88.

Müller, J.C., 2009, 'Transversal rationality as a practical way of doing interdisciplinary work, with HIV and AIDS as a case study', Practical Theology in South Africa 24(2), 199-228.

Müller, J.C., 2011, 'Postfoundational practical theology for a time of transition', HTS Teologiese Studies/Theological Studies 67(1), Art. 837, 5 pages. http://dx.doi. org/10.4102/hts.v67i1.837

Seeking, J. \& Nattras, N., 2005, Class, race, and inequality in South Africa, Yale University Press, New Haven, CT. http://dx.doi.org/10.12987/yale/9780300108927.001.0001

Shrag, C.O., 1992, The resources of rationality: A response to the postmodern challenge, Indiana University Press, Bloomington, IN.

Struwig, J., Davids, Y.D., Roberts, B., Sithole, M., Tilley, V., Weir-Smith, T. et al., 2011 'Towards a social cohesion barometer for South Africa', Research report sponsored by the Programme to support pro-poor policy Development, viewed 02 July 2014 from http://www.psppd.org.za/MediaLib/Downloads/Home/ResearchEvidence/ Towards\%20a\%20social\%20cohesion\%20barometer\%20for\%20South\%20Africa. pdf

Taylor, C., 1989, Sources of self: the making of modern identity, Cambridge University Press, Cambridge.

Van Huyssteen, J.W., 2000, 'Pluralism and interplinarity: In search of theology's public voice', in C.W. du Toite (ed.), Evolution and creativity, pp. 217-249, Research institute for theology and religion, UNISA, Pretoria.

Van Huyssteen, J.W., 2006, 'When our bodies do their thinking: Theology and science converge', American Journal of Theology and Philosophy 27(2), 127-153. 